The Brock Review Volume 12 No. 1 (2011)

(C) Brock University

\title{
One of Every Type: Collection, Description and the Production of the Generic Animal at the
} Hamburg Zoological Garden, 1863-1911*

Angeles Espinaco-Virseda

\begin{abstract}
Between 1863 and 1911, the guidebooks and several other publications of the Hamburg Zoological Garden characterized animals as standardized, biologically determined "Types." These typologies were reinforced by physical and anthropomorphic descriptions and representations of animals as commodities or fragmented objects of scientific scrutiny. In this way, attempts to classify and collect animals reduced them to unsophisticated, interchangeable objects that confounded the zoo's mandate to deepen public and scientific knowledge about wild animals. Instead, captive wild animals were rendered as simplified and generic representations that called into question the authenticity of the zoo experience and the scientific premise of the zoological garden.
\end{abstract}

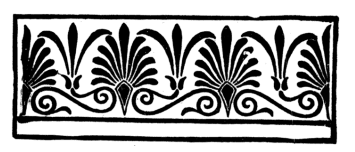

"It was a beautiful summer morning when Karl and Wilhelm, two boys of the ages 10 and 12 years, walked at the side of their beloved father towards the city. The boys were full of joy and pleasure as their father had promised them a visit to the famous zoo, there, in that very place. . . They had only just entered through the beautiful pergola at the zoological garden . ." when they were met by the "proud ruler of the animals," the lion, to whose growls they were immediately drawn. After viewing the lions the trio moved hastily to the next cage, that of the "bloodthirsty tiger" and then on to "the polar bears, the most dangerous predator[s] of the high North". And so they continued through the various exhibits in the zoo until eventually the father and sons concluded their swift tour, bringing the account of their zoological excursion to a close with a description of a pelican, whose "exceptionally long beak," possessed "a skin sack for the accommodation of caught fish". ${ }^{1}$ 
In his short illustrated book, $A W$ alk through the Zoological Garden (Gang durch den zoologischen Garten), Ernst Treuberg recounted in pictures, prose and verse a family outing to an unnamed German zoo. As seemingly personalized as the book was in reproducing the trio's journey and impressions of the zoo the book was also surprisingly generic in its reductive and essentialized representation of the animal inhabitants. ${ }^{2}$ Indeed, in this sense, Treuberg's account resembled a Guide through the Zoological Garden of Hamburg (Führer durch den Zoologischen Garten zu Hamburg), which framed and informed zoo visitors' - and perhaps even Treuberg's - perceptions of the animals there, but which paradoxically did not truly reflect the wild animals it described.

Beginning in the late 1850s, a wave of public zoos emerged across the German States. Among them was the Hamburg Zoological Garden which opened in May 1863. Like many of its German contemporaries it was founded through a society of shareholders and had the dual mandate to provide citizens with a place of leisure and to advance scientific knowledge. Indeed, to this end, between 1863 and 1911, the Hamburg Zoo sold handbooks that guided visitors through the zoo and enabled visitors to learn more about the zoo's animals. In addition, the zoo also briefly published a newspaper, the Zoological Garden Reporter (Zoologischer Garten-Anzeiger), and a small magazine called the The Zoological Garden in Hamburg (Zoologischer Garten in Hamburg). ${ }^{3}$ A critical aspect of fulfilling the zoo's scientific and educational mandate was to systematically collect and categorize animal species for display. As one contemporary journalist explained about public zoos in general, "In the zoological garden stand as many species as possible with a single or several representatives on display, mostly in narrow cages or also in larger enclosures, but always strictly separated according to species."4 Although a systematic close reading of other German zoological gardens would reveal if this approach to collection engendered a more generalized discourse, this paper illuminates the way in which the Hamburg Zoological Garden's attempts to educate visitors about the characteristics of the various animal species were controverted by its approach to the classification and description of its collection. ${ }^{5}$ In this way, it will call into question the nature of the Hamburg Zoo's approach to animal collection.

In this paper, I examine the representation of animals in various publications of the Hamburg Zoological Garden to show that particular approaches to the description and portrayal of animals reduced them to simplified, standardized and interchangeable objects that confounded the zoo's mandate to deepen public and scientific knowledge about animals. I begin by briefly discussing the importance and role of animal collecting at the Hamburg Zoo. Next, I specifically consider the 
Hamburg Zoo's publications to discuss how the combination of both anthropomorphic and physical descriptions served to characterize animals as standardized "Types" intended to represent all animals of a particular species. Last, I argue that these reductive typologies were reinforced by descriptions, perspectives and images that objectified animals, which were often presented literally as commodities or fragmented objects of scientific scrutiny and underscored their status as unsophisticated and generic objects. In this way, the captive animals represented at the Hamburg Zoo failed to capture the complexity of their wild counterparts, calling into question the authenticity of the zoo experience and, with that, the premise of the zoological garden.

Thus, I begin by briefly describing the importance and role of animal collecting at the Hamburg Zoo. As the seventh zoo to open in the German states the Hamburg Zoo was a relative latecomer to the scene. Nevertheless, since it was centrally located in a port city it was wellpositioned to become one of Germany's leading zoos. Until approximately 1883 the variety of its collection was unsurpassed and even then only by the Berlin Zoo. ${ }^{6}$ In the second half of the nineteenth century, having a zoo was a civic status symbol. ${ }^{7}$ In turn, the size and completeness of an animal collection determined the zoo's own importance among other institutions. At the height of the Hamburg Zoo's success, just prior to World War I, examples of 1,000 different species could be found within its collection of 4,000 animals. ${ }^{8}$ As Dr. Julius Vosseler, one of the Hamburg Zoo's director's described it, easy access to animals from abroad made it possible for the Hamburg Zoo to "gather valuable particulars about the natural life and existence of foreign animals in their homeland; to bring, for the first time, many species to the attention of science or to have them reproduce; and to take on or to send the other zoological gardens the foreign animals that arrive that are appropriate to their specialties, once again, affording considerable service to the assistance of the general public." Clearly, the director regarded a large and varied collection of animals as critical to the zoo's mission. ${ }^{10}$

In this way, Hamburg's advantageous location encouraged and facilitated the zoo directors' zeal for collecting, but Vosseler's comments also reflected a belief in the scientific value of collecting in and of itself. Indeed, the enthusiasm for collection was underpinned by the notion that to know one animal of a particular species or sub-species was to know all animals of that particular species or sub-species. In other words, essential knowledge of an animal "Type" could be obtained through its possession and through observation of its physical and mental characteristics. In its intent the zoological garden resembled the anthropological Typensammlung (literally, a collection of Types), which was a collection of human and/or cultural artefacts meant to characterize supposed ethnic and 
racial types according to their common physiological traits (albeit based on mass observation) and/or cultural and psychological traits. To be sure, the notion that one animal could represent all animals of its type was the very premise of the zoo. ${ }^{11}$

Accordingly, when visitors to the Hamburg Zoo followed the guidebooks and systematically moved from display to display, they were presented with a descriptive portrait of each animal - an animal typology based on physiological and sometimes anthropomorphic characteristics that were also portrayed in the zoo's other publications. In themselves, these descriptions suggested that all the characteristics of a particular type of animal were standard and embodied by the individual representative found in the enclosure. So, for example, the zoo's first director, Dr. Alfred Brehm, whose renown as a naturalist also conferred scientific authority on his subjective judgments, declared in the zoo's first guidebook that llamas are "In their mental nature . . . all the same; they are stupid, stubborn and malicious." 12 Although this tendency to generalize was especially evident in Brehm's expansive and anthropomorphic descriptions, Bolau also stated unequivocally that the speckled mudhen (gesprenkelte Sumpfhuhn) “. . . accustoms itself easily to captivity and quickly gives up its initially shy, hidden nature."13 Equally, Vosseler stated that the Central European Red Deer (the Edelhirsch, literally "the noble stag"), was "smaller, but more handsome and of a prouder build and bearing than the Wapiti." ${ }^{\prime 14}$ Without a doubt, the assumption that all animals of a particular type were uniform enabled these directors to speak about both temperament and/or physique as though they were invariable.

Moreover, the Hamburg Zoo literature frequently characterized such animal "Types" as a combination of both physical and mental attributes. ${ }^{15}$ For instance, in describing martens, Brehm declared that "All characteristics and requirements of real predators are united within them: [a] suitable physical build, that is, [a] slender body, sharp teeth and claws for climbing, agility and dexterity, sharp senses, intelligence, cleverness, cunning and [an] insatiable thirst for blood." ${ }^{\text {16 }}$ By the same token, the Hamburg Zoo's second director, Dr. Heinrich Bolau, described Rhesus monkeys as "large, strong animals with the head of a dog, cheek pouches and very developed weals on their buttocks," whose "fury, cunning and malice" made them unpopular in their homeland. ${ }^{17}$ Even the zoo's last director, Dr. Vosseler, whose concision generally avoided anthropomorphism, occasionally strayed into such portrayals, describing all varieties of baboon as "Characterized by their size and strength, also, above all, by their ugliness. Their natures are also as spiteful and cunning as their eye[s], especially as he [the baboon] is the tyrant of the weaker members of the known males in their 
horde." In fact, in another example, even more directly to the point, Vosseler simply declared that the "nature and build" of the parrot was "extremely characteristic". ${ }^{18}$

Thus, by describing animal "Types" in general terms and by mixing descriptions of psychological qualities with physical traits, the zoo's directors gave the impression that all of the characteristics they described were innate and linked and therefore did not vary within a species or sub-species. Indeed, the notion that these qualities were uniform and biologically determined was critical to the zoo enterprise, which sought to display representatives of every animal Type.

In a sense, the use of individual captive animals to represent all animals of the same Type was the equivalent of the way in which anatomical illustrations of the human body stood for an idealized norm. The historian Thomas Laqueur has shown that illustrations representing "the human eye or the female skeleton ... must postulate a transcendent norm. But there is obviously no canonical eye, muscle, or skeleton, and therefore any representation making this claim does so on the basis of certain culturally and historically specific notions of what is ideal, what best illustrates the true nature of the object in question." ${ }^{19}$ By the same token, captive animals and their accompanying descriptions were intended to represent a 'true' but nevertheless idealized version of each type of wild animal. Individual animals, which might be exceptionally sick, weak, clever or stupid, for example, were not what was desired for display.

Occasionally, when an animal at the zoo was recognized as an individual, it could still be used to support generalizations. For example, according to Brehm, the hawk is "a highway robber and a tramp of the worst kind. Our young female strangled and devoured her older mate - and certainly not out of love! More need not be said about the character of the hawk." ${ }^{20}$

Furthermore, an example from Bolau's series on "Our Beavers" illustrates not just the way in which the author moved easily between references to animals in general and animals in particular, but also shows how anthropomorphism, which might have individualized animals, was actually compatible with this process of generalization. First, the article began by broadly and briefly discussing the appearance and abilities of infant beavers as a whole. Bolau then continued by describing the antics of the zoo's "two offspring - we would almost like to call them Max and Moritz" and the care given by "Frau Mama" and "Herr Papa" beaver. ${ }^{21}$ Yet, although this anthropomorphism humanized and individualized the animals to some extent and, in this case, made them endearing, their anthropomorphic representation was never truly separate from their generic representation. Indeed, Bolau concluded his article by explaining that the zoo had previously possessed other beavers. Although they eventually perished, he matter-of-factly explains, "it took a 
long time to replace them; only last year the opportunity presented itself to buy a nice pair of Canadian beavers." 22 In this way, despite the seeming individualization of the zoo's animals, they were still only interchangeable representations of Types.

In fact, even where there were exceptions to the standard characterization these did not undermine, but could rather be used to underline the rule by drawing attention to it. For instance, Dr. Vosseler remarked that although normally cross adders (Kreuzotter) refused to eat in captivity, on the contrary the one held by the Hamburg Zoo had repeatedly taken food. ${ }^{23}$ Similarly, Brehm described canines as "only brave when they are driven by hunger - and it is exactly for this reason that our domestic dog makes such a notable exception among his familial kin." ${ }^{24}$ In this way, the importance of variation was negated by reference to the presumed norm.

Yet, this brings me to my final point, which considers some of the particularly reductive practices used in the Hamburg Zoo publications, which reinforced the idea of generic animal “Types" by suggesting that animals were objects and therefore uniform and interchangeable. The tendency to reduce animals to physical objects, either as a whole or, literally, as pieces sometimes took the form of explicit commodification. Clearly, in the world of science and public education, there was a trade in animals. For instance, the Hamburg Zoo had an arrangement with the Hamburg Natural History Museum whereby the zoo donated the bodies of deceased animals, worth about 2,000-3,000 Marks annually, to the museum to make use of their hides and skeletons. In exchange, the museum provided the zoo with necropsy results for each animal as well as access to the mounted specimens, which were used for lectures given to zoo shareholders and subscribers. ${ }^{25}$ However, the commerce in animals was also made apparent to visitors when aquarium and breeding animals as well as animal antlers and surplus animals were advertised for sale in the Zoologischer Garten-Anzeiger, for purchase from the Hamburg Zoo by anyone with the money. ${ }^{26}$

Furthermore, in trying to provide the public with useful information about animals, all of the directors frequently commented in their handbooks on the taste of an animal's meat or pointed out other products, such as fur, which could be taken from an animal's body. ${ }^{27}$ For instance, Dr. Brehm explained about the Fausthubn, a wild fowl, that "Its meat is pleasant tasting, but tough. Nevertheless this is the reason for the persecution, which the flying fowl must suffer from humans and desert predators." ${ }^{28}$ Similarly, Dr. Bolau explained, that in its homeland the yak had long been domesticated, adding that "His significant physical strength can be used to advantage for pulling and carrying loads; milk and meat are pleasant tasting; the hair and especially the tail are highly prized - these as decorative objects and signs of rank - he is the so-called horsetail of the Turks." ${ }^{29}$ Clearly, references 
to the commodities which could be extracted from animals not only objectified them, but in some sense reduced them to an assemblage of mere parts representing diverse products: flesh, milk, tail, teeth, skin and even physical labour. As Carol Adams has pointed out, just as fragmentation in representations of women's bodies strips them, as objects, of any reference to their subjective selves so, too, does the fragmentation of animals' bodies. ${ }^{30}$

Furthermore, even though all of the Hamburg Zoo directors used these kinds of descriptions, the illustrations in many of the guidebooks added a further dimension to this treatment of animals. In the 1865 edition of Brehm's handbook, there were twelve images. ${ }^{31}$ At first glance, these illustrations are unremarkable. With the exception of an image of birds at the zoo's waterfall grotto, ${ }^{32}$ all of the illustrations showed the physical structure of an animal enclosure - buildings, bars and fences - thereby implicitly or explicitly situating the animals directly within the zoo and its enclosures (Figure 1).

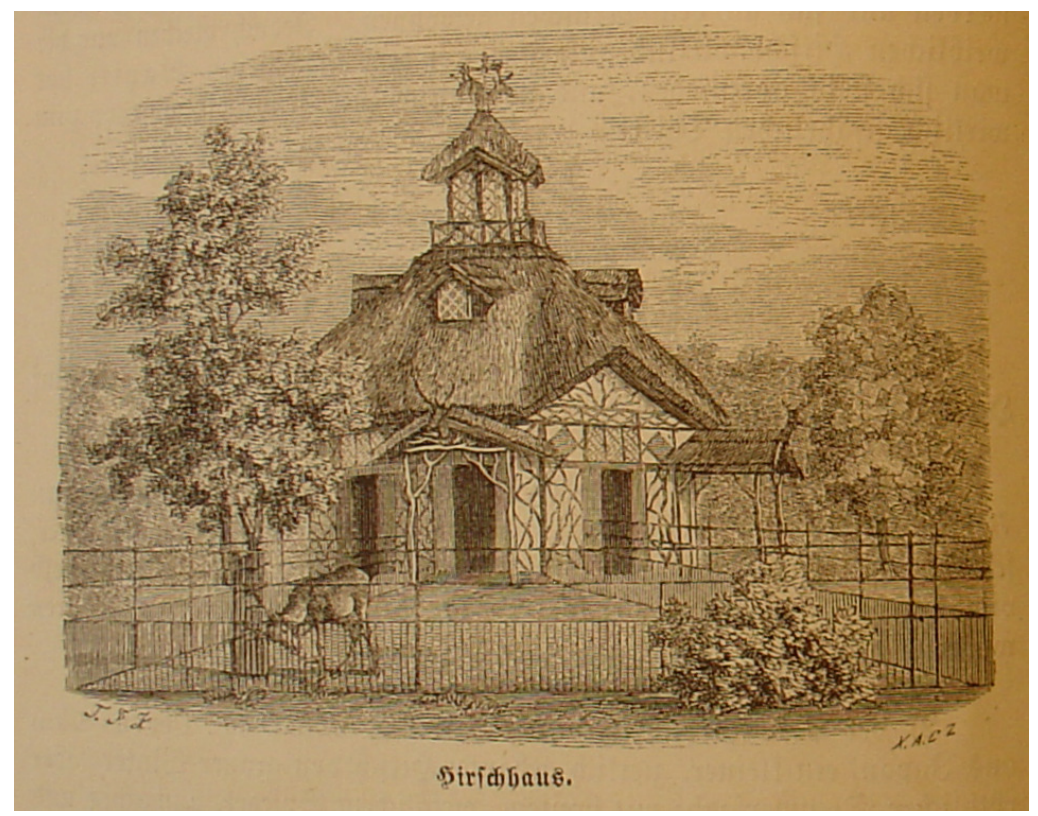

Figure 1. "Deer House." (StaHH A585 - 159 Kapsel 1, Zoologischer Garten: A. E. Brehm, Führer durch den Zoologiscben Garten zu Hamburg [1865], 4). ${ }^{33}$

Much like a photograph, these images conveyed the actual appearance of the zoological garden and replicated the visual experience of the zoo visitor. Yet of these twelve illustrations, seven of them also depicted zoo visitors as they viewed the captive animals thereby drawing attention to the act of observation itself (Figure 2).

In this way, the positions of zoo visitors as observers and the captive animals as the observed were clearly articulated. With only one exception, there is no possibility of an alternative view, of 
seeing the animal's perspective looking out from within the enclosure towards the zoo visitors. ${ }^{34}$ In all of these types of illustrations, the visible barriers of the enclosures demarcate the boundaries between humans and animals and suggest the perspective of the visitor, while images of people looking at the confined animals within further reinforced the distinction between visitor and captive, human and animal, subject and object.

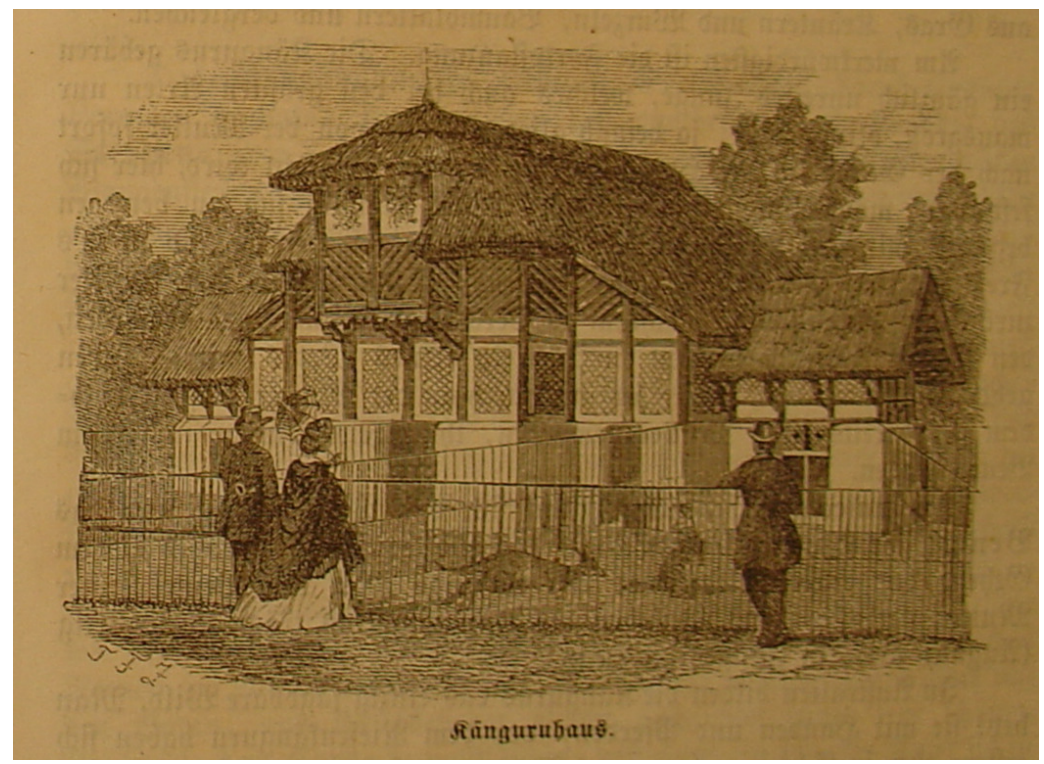

Figure 2. "Kangaroo House.” (StaHH A585 - 159 Kapsel 1, Zoologischer Garten: A. E. Brehm, Fübrer durch den Zoologischen Garten zu Hamburg [1865], 19).

In fact, in none of the images did animals look towards the observer. The animals were always shown as completely indifferent to zoo visitors. Indeed, in many cases, such as those of the kangaroo house, the predatory bird cage and the "wolf's lair," the enclosed animal is barely visible, or as in the cases of the "predator's gallery" or the bear's cage, not visible at all! ${ }^{35}$ It was only the house or enclosure and the people moving towards it or looking into it that were depicted. In other words, in no case in these illustrations did animals observe humans. When animals were depicted they were the objects of attention. When they were not shown, it was the human act of observation that was represented. In this way, the status of the zoo visitor as a subject was reinforced by the privileging of his or her perspective.

However, the representation of animals in Brehm's guidebook was not the only approach used. Indeed, his tenure at the zoo was short. Brehm left in 1866, after only 3 years as the Hamburg Zoo's director. ${ }^{36}$ Afterwards, the zoo continued with the acting leadership of various individuals for 
nine more years. ${ }^{37}$ Then, under the zoo's subsequent director, Dr. Heinrich Bolau, who assumed the position in 1875, the handbooks eventually underwent a number of changes. Still, Dr. Bolau, whose tenure spanned 34 years from 1875 to 1909, reinforced and modified the objectification of animals through the addition of an intense scientific gaze that also fragmented animal bodies although in new ways. Among the 22 illustrations found in the 1891 zoo guide, 4 of the 14 new images showed only
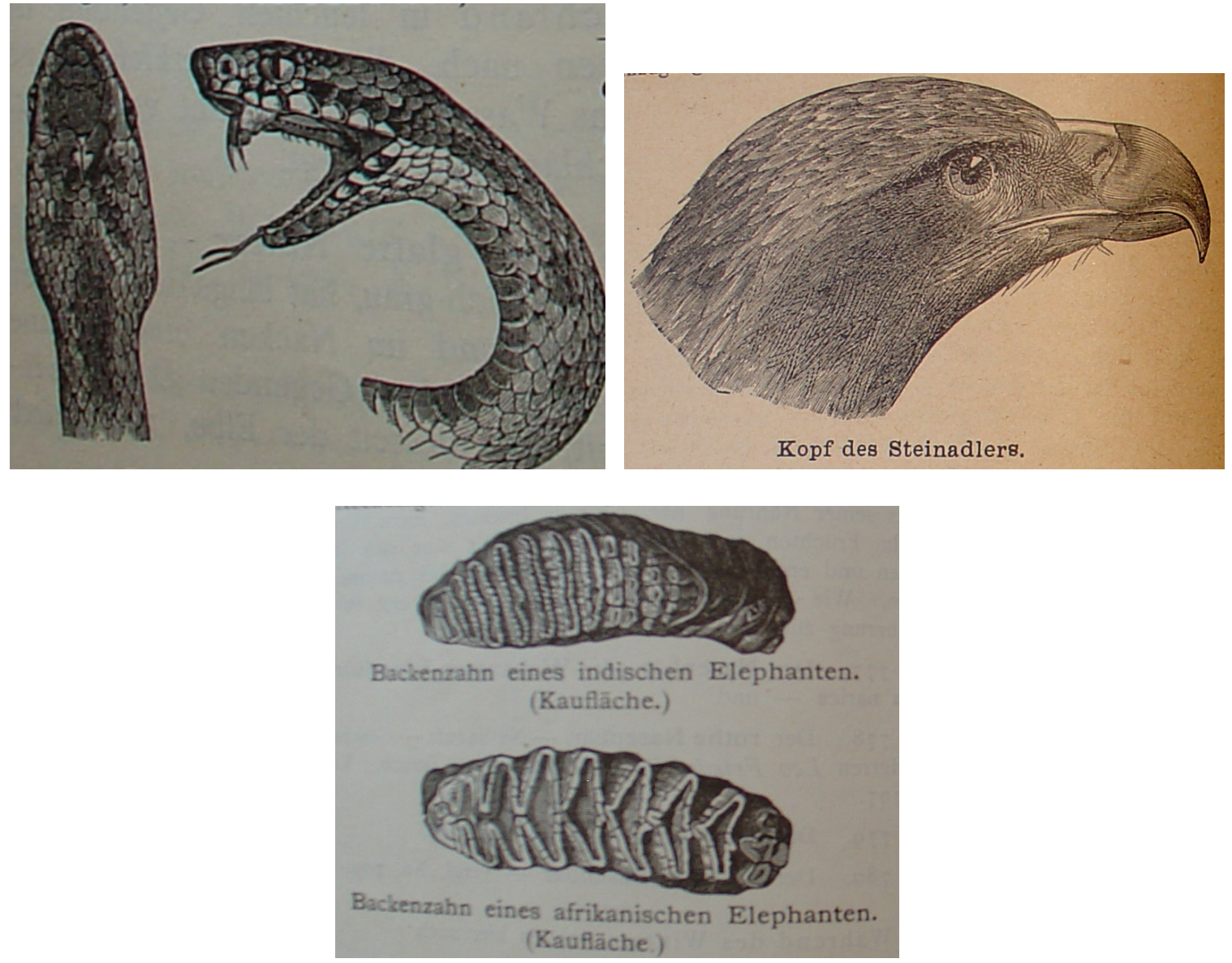

Figure 3. "Head of the cross adder." (StaHH A585/159 Kapsel 1, Zoologischer Garten: Heinrich Bolau, Führer durch den Zoologischen Garten zu Hamburg [1891], 39).

Figure 4. "Head of the golden eagle." (StaHH A585/159 Kapsel 1, Zoologischer Garten: Heinrich Bolau, Fübrer durch den Zoologischen Garten zu Hamburg [1891], 8).

Figure 5. Molars of an Indian and African elephant. (StaHH A585/159 Kapsel 1, Zoologischer Garten: Heinrich Bolau, Fübrer durch den Zoologischen Garten zu Hamburg [1901], 116).

isolated parts of the animals in question. For example, they depicted a top view and profile of a snake's head showing its fangs and tongue, an eagle in profile and a comparison of African and Indian elephant teeth showing a top view of their molars (Figures 3, 4 and 5). ${ }^{38}$ Although these were 
not the predominant form of representation in this guidebook - there were also 9 new images showing animals in a natural setting, which I will return to later - these images of fragmented, decontextualized bodies nevertheless suggested the scientific tendency to isolate animals into representative biological components for more detailed study.

To be sure, Bolau was a scientist in his own right. Not only had he been a member of the Hamburg Natural Science Society and a Headmaster for Nature Studies at the Johanneum High School in Hamburg, but he had also published work on ornithology. Furthermore, such images reflected Bolau's zoological training at the University of Giessen with Dr. Rudolf Leuckart, an important comparative anatomist. ${ }^{39}$ Fittingly, an article about predators in the Zoologischer GartenAnzeiger, which was published during Bolau's tenure, stated "If we dissect the animals more precisely, then we find the following more or less general characteristics in the build of the predator." The article then continued its anatomical analysis in tremendous detail. ${ }^{40}$

Certainly in anthropology the painstaking reduction of the body of the Other into anatomical parts deemed to characterize particular races was not an unusual endeavour. Indeed, the 50 pages of analysis in works such as $A$ Contribution to the Craniology of the Eskimo (Ein Beitrag zur Kraniologie der Eskimo), by Dr. Bruno Oetteking, illustrates the extent of this type of scientific interest. ${ }^{41}$ The pursuit of physiognomic truths led both to the literal sectioning of human bodies into constituent parts, especially skulls, but also to their figurative sectioning through the minute examination and precise analysis of human remains. Animals appear not to have been different from human specimens in this respect.

Indeed, had it not been for the visible absence of medical equipment in some of the guidebook's fragmented images, the visual profiles such as that of a snake and a warthog would have resembled those found in medical illustrations of vivisections (Figures 6, 7,8 and 9). To be sure, the visual perspective in the handbook suggested the particularized gaze of the scientist intent on the investigation of a specific anatomical or physiological question. Furthermore, the anatomical detail of the images was so precise that it might as well have replicated the actual visual experience of a vivisection. These images, not to mention the descriptions, of fragmented and decontextualized animals directed an analytical gaze toward the details of the body, emphasizing its ostensibly universal physical qualities. 

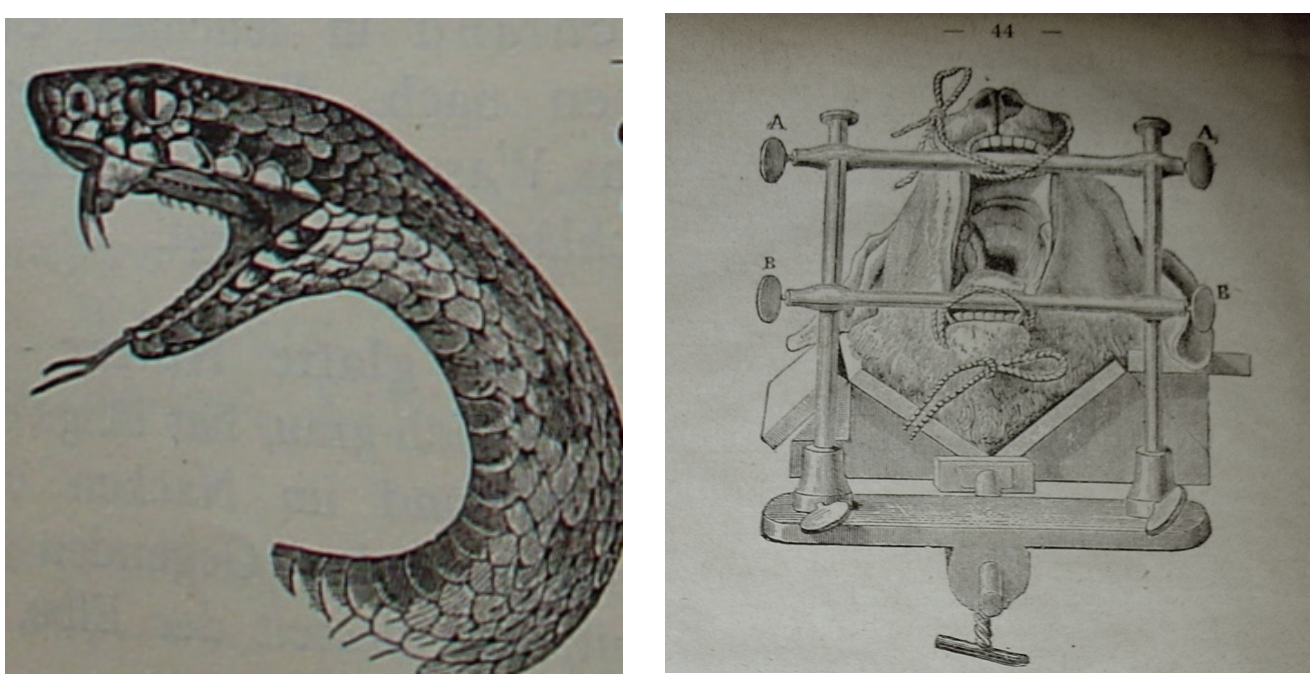

Figure 6. "Head of the cross adder." (StaHH A585/159 Kapsel 1, Zoologischer Garten: Heinrich Bolau, Führer durch den Zoologischen Garten zu Hamburg [1891], 39).

Figure 7. Vivisection of a dog. (Bibliothek des Ärtzlichen Vereins, Herman Stenz, Die Vivisektion in ibrer wabren Gestalt. Unwiderlegliche Tatsachen aus der Facbliteratur [Berlin: Weltbund zur Bekämpfung der Vivisektion, n.d], 44).
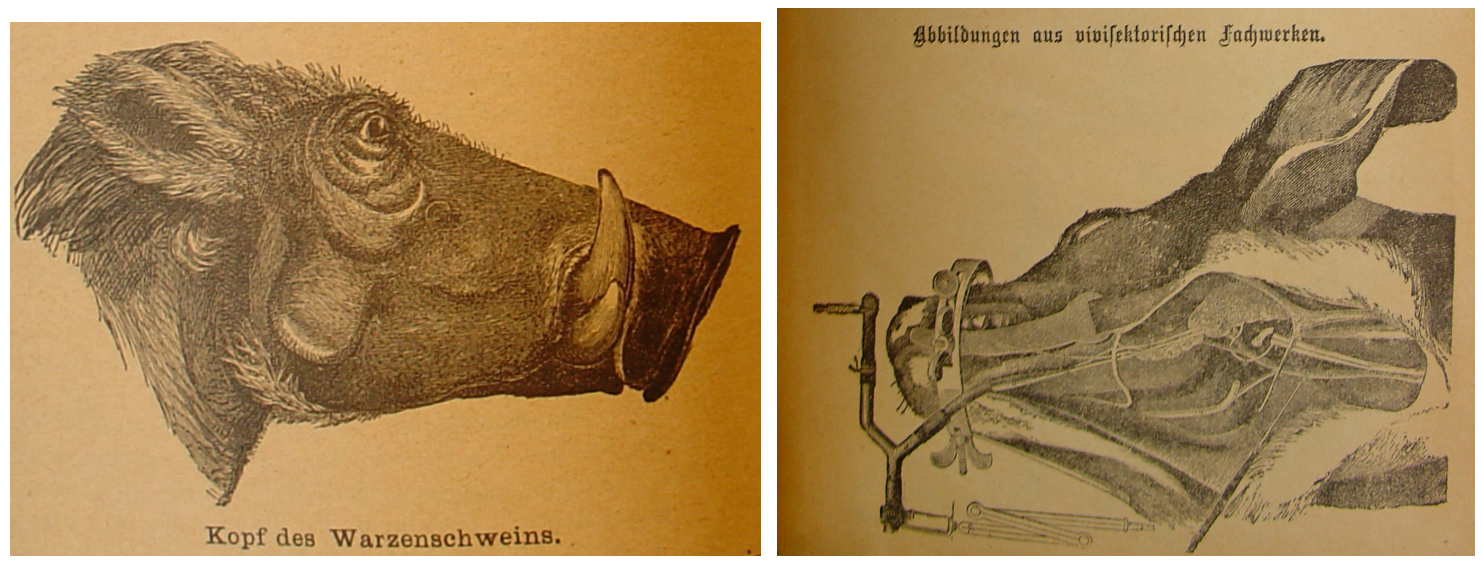

Figure 8. "Head of the wart hog." (StaHH A585/159 Kapsel 1, Zoologischer Garten: Heinrich Bolau, Fübrer durch den Zoologischen Garten zu Hamburg [1891], 52).

Figure 9. "Illustration of a vivisection from specialist literature." (Bibliothek des Ärtzlichen Vereins, Herman Stenz, Die Vivisektion in ibrer wabren Gestalt. Unwiderlegliche Tatsachen aus der Facbliteratur [Berlin: Weltbund zur Bekämpfung der Vivisektion, 1899], 43).

On the other hand, by 1901 illustrations showing animals in the zoo's own enclosures had been completely eliminated. They were replaced mostly by additional illustrations of animals in naturalistic settings. These supplemented the guidebook's fragmented images, visually "capturing" animals in such a way as to encourage narrative fantasy - as though a hunter, adventurer, animal 
collector or natural scientist on an expedition had just happened upon the object of his pursuit (Figures 10 and 11). ${ }^{42}$

Indeed, a striking illustration ca. 1890-95, likely for a periodical, shows a wild boar fleeing through the forest. Although the boar's dynamism would have been unusual for a handbook illustration, the tightly framed image of an animal in its natural habitat could otherwise easily have been used in the zoo guide - except that the boar's body was marked with a target - the title of the image (Figure 12). Taken together, the zoo guide's detailed and realistic illustrations of animals in both fragmented isolation and in their natural settings suggested a gaze that focused attention specifically on animals' bodies as objects.

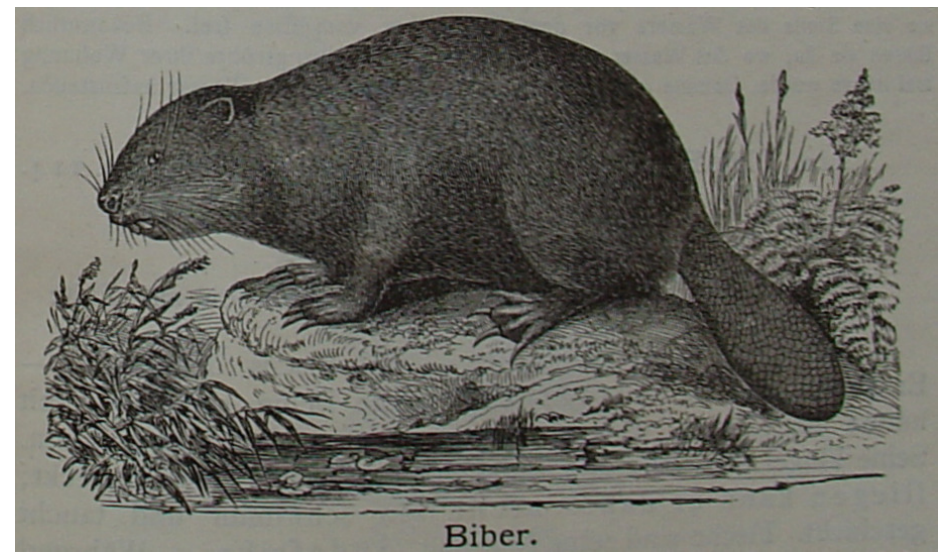

Figure 10. "Beaver." (StaHH A585/159 Kapsel 1, Zoologischer Garten: Heinrich Bolau, Führer durch den Zoologischen Garten zu Hamburg [1891], 22).

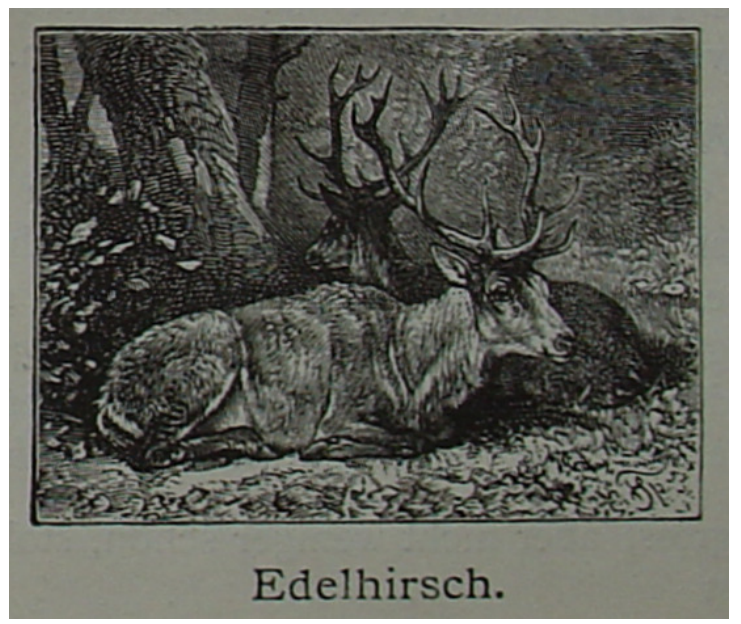

Figure 11. "Central European Red Deer." (StaHH A585/159 Kapsel 1, Zoologischer Garten: Heinrich Bolau, Fübrer durch den Zoologischen Garten zu Hamburg [1901], 1). 


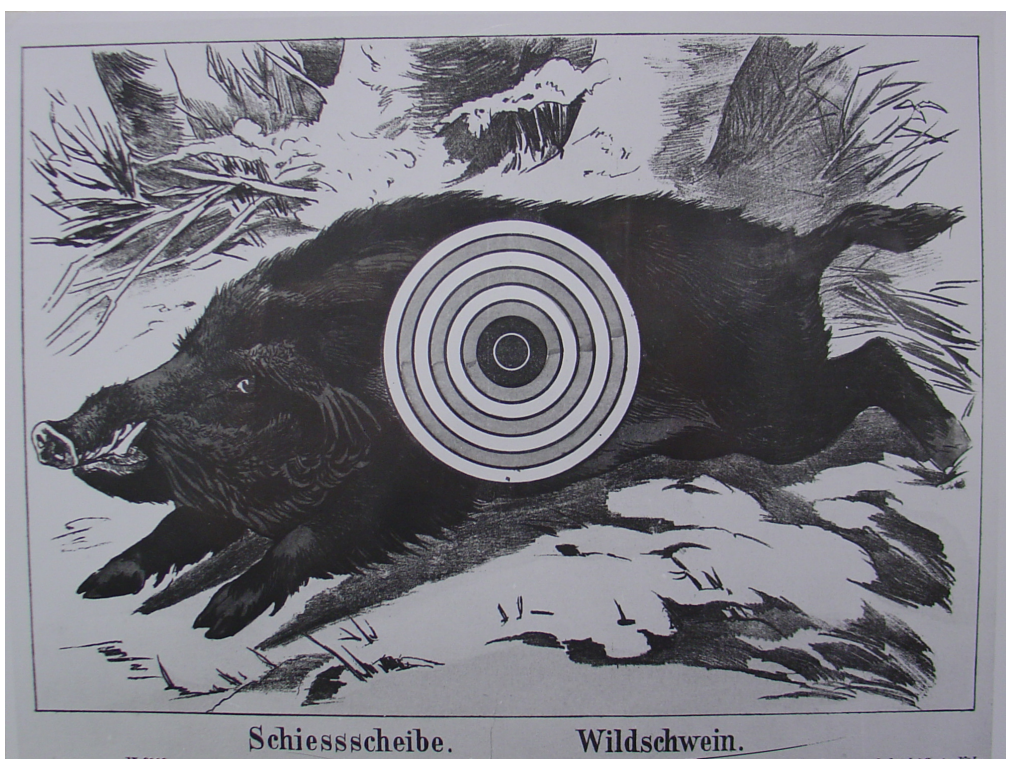

Figure 12. “Target. Wild boar.” (“Bilderbogen Schiessscheibe”, Verlag Gustav Kühn, Neuruppin. Reprinted by permission of the Stiftung Historische Museen Hamburg/Altonaer Museum).

To be sure, this gaze was reflected in and even fostered by the guidebooks, which taught zoo visitors how to observe animals by directing their attention to specific identifying characteristics and anatomical details. As a result of the large number of animals in the Hamburg Zoo's collection it appears to have been necessary for the guidebooks to be brief in their descriptions. In Bolau's handbooks, the majority of entries were limited to one or two sentences describing either geographic distribution, diet, appearance, temperament, utility or some combination of these (plus the name and location of the animal's donor if there was one). So, for instance, a typical entry, such as that for a macaque called the "Schweinsaffe", literally "swine ape", stated that it "takes its name from the short, somewhat turned tail that is not unlike the same body part of a pig. From Java, Sumatra and Borneo." ${ }^{43}$ Where the animals, such as birds, were very numerous, the book's descriptive comments were often even briefer: "The Sun Parakeet [emphasis original] - Conurus solstitialis - very rare; predominantly splendid yellow and red. Gift of Mr. Carl Heidorn in El Callao, Venezuela." ${ }^{44}$ If anything then, time and space considerations necessitated a reductive approach to the animals' descriptions.

Nevertheless, despite the need to efficiently catalogue a great number of animals, the zoo guides still had to point out details that would aid visitors in identifying and distinguishing the 
animals from one another. Thus, it was not uncommon to find very precise entries remarking on subtle or minute characteristics. For example, the Nilgai (Nilgau-Antilope) was described as “... large, long-legged, less slender than her relatives." 45 The sable antelope (Rappen-Antilope) was "one of the most imposing antelopes, is deep black-brown in colour and has an upright mane on its neck." ${ }^{\text {46 }}$ In comparison the gazelles were "small, highly delicate little animals of the most slender build and light brown colouring. The beauty of their eyes is well-known." ${ }^{\prime 47}$ Thus, the use of meticulous description focused visitors' attention on the body making it the primary means of animal identification, implicitly encouraging the notion that animals were fundamentally interchangeable physical entities.

Likewise, a variation of this trend was continued under the directorship of the zoologist Dr. Julius Vosseler, who assumed his role in 1909 after working for the Prussian government at a biological/agricultural institute in German East Africa. ${ }^{48}$ In Vosseler's guide, a pronounced scientific detachment was manifested by his significantly brief remarks about animals, which were primarily identified by their geographic distribution and a short physical description. ${ }^{49}$ Most comments were only a sentence long. Generally, Vosseler's remarks did not extend beyond two sentences, unless elaborating on an animal especially uncommon in zoos, such as the beaver. Unusual animals such as the kangaroo also received somewhat more attention. ${ }^{50} \mathrm{~A}$ typical catalogue entry, like that for polar bears, stated the animal's Latin name and that it was "mainly carnivorous, swims and dives superbly, hunts fish, seals, etc. North. Polar region." ${ }^{51}$ In another example, the serval cat was simply described as "long-legged and short-tailed, with noticeably small head and large ears. S. and Middle Africa." 52 Indeed, in the most extreme examples of brevity an animal was identified only by its scientific name and geographic distribution or only by the common and Latin names. ${ }^{53}$ As a result, the guidebook was almost devoid of subjective evaluations of the animals. Instead, most animals were stripped of all characteristics, or if at all, only those pertaining to their anatomy and abilities were mentioned.

Put another way, such descriptions suggested that the best way to know and understand animals was through their bodies. For example, another article in the Zoologischer Garten-Anzeiger series on "Our Predators" made this explicit by arguing that "In their entire nature, dogs show that they are much less dependent on exclusively animal nourishment and permit the conclusion that accordingly, they will also be less murderous and greedy for blood than cats are. ... The facial expression shows this very clearly, as the dog's face speaks to us in a friendly manner and never lets the defiant selfconfidence and the wildness that are revealed in the cat's face, become especially noticeable." ${ }^{54}$ Clearly, this kind of description expressed a belief in physiognomy, the notion that physical appearance was an expression of character. As it did in humans, it also presumed that animal 
"Types" were uniform and biologically determined. They did not vary between individuals: animal traits and temperaments were fixed and interchangeable and located within the body.

Finally, it must be understood that in seeking to amass a large collection of "Types" the Hamburg Zoo was able to justify its existence from a conservationist position through the acquisition of endangered species. Hamburg Zoo literature produced by all three of the zoo's directors frequently pointed out instances where species in its collection were rare or threatened by extinction. ${ }^{55}$ Just as the Typensammlungen of anthropological museums sought to preserve and display the artifacts of far-off dying peoples and cultures, the zoo represented itself as a reserve for rare and vanishing species. ${ }^{56}$ But, like any artifact or cultural remnant, once it was removed from its original context, its meaning changed and was often diminished through the reductive exercise of labeling and description.

Likewise, animals which might in the complexity of their natural environment have exhibited more individualized and varied behaviours were reduced to static and simplified generic objects. ${ }^{57}$ Indeed, one contemporary writer in a Hamburg Zoo newspaper article even lamented that this was a problem of zoos in themselves. Despite quoting a lengthy exposition by Dr. Brehm about the many qualities of the parrot, including that it was proud, brave, loyal, hot-tempered, cruel and cunning, the author ultimately concluded that Brehm's observations mainly reflected the qualities of captive animals. In fact, the article's author conceded, "In their nature, however, they show considerable variations, ... All of these characteristics become modified through captivity and taming, at times they are even totally changed, so that we no longer believe that we have any kind of parrot in front of us at all." 58

In conclusion, the zoological endeavor to collect and categorize animals was underpinned by the use of physical descriptions alone or combined with anthropomorphism to characterize animals as Types. These typologies were reinforced by images and descriptions that objectified animals and sometimes reduced them to commodities or to fragmented objects of scientific scrutiny. Indeed, the body was isolated and represented as the key to classifying and characterizing animal Types, yet such attempts at classification only made the animals appear uniform, unsophisticated and interchangeable. Ironically, as a result, although the Hamburg Zoological Garden had been founded with the intention of advancing scientific and public knowledge about wild animals, through this very endeavor its goals were confounded. Ultimately, it was a problem of the concept of collection in itself that the zoo succeeded only in conveying generic and simplified representations of captive animals. 


\section{Notes}

* An earlier version of this paper was presented at the conference "Animals and Animality Across the Humanities and Social Sciences” at Queen's University, Kingston, Ontario (June 26-27, 2010). The author gratefully acknowledges the support of the University of Alberta Graduate Students' Association and the Social Sciences and Humanities Research Council of Canada: Aid to Research Workshops and Conferences in Canada Grant.

The author wishes to thank John Buhler, Allan Rowe and her anonymous readers for the careful readings and thoughtful comments they contributed to this article.

${ }^{1}$ Author's collection: Ernst Treuberg, Gang durch den Zoologischen Garten [no publishing information, c. 1900], n.p.). All translations in this paper are the work of the author.

2 The book is divided into two parts. The first part consists of a series of poems illustrated with coloured drawings of the relevant animals, presented in the same order as is recounted in the second part of the book in which the author uses a third person narrative to describe the father's journey with the two boys.

${ }^{3}$ A fourth publication, the book Pictures and Sketches from the Zoological Garden of Hamburg (Bilder und Skizzen aus dem Zoologischen Garten zu Hamburg) by R. L. Brehm (Hamburg: M. H. W. Lührsen, 1865), also showcased and described the zoo's inhabitants for both a popular and a specialist audience. However, my focus in this paper is limited to materials that likely accompanied the zoo visitor on his/her excursion and which therefore most directly structured and shaped the zoo experience. As suggested in the article's prologue above, zoo handbooks played a most important role in informing the visitor's perceptions. Guidebooks advised the best route and approach to systematically viewing the animals and were intended to be used at the time of the visit. Similarly, the magazine, The Zoological Garden in Hamburg, provided the zoo's concert listings, making it helpful to have in-hand, but it also provided articles related to its exhibits. Furthermore, the magazine and the handbooks were relatively inexpensive and available for purchase at the zoo. In 1891, the handbook cost 30 Pfg. The magazine, of which copies are available for the years 1904-1907, cost 10 Pfg. The zoo newspaper, the Zoological Garden Reporter, for which some copies from the year 1880 are available, was free of charge and was therefore available to all zoo patrons. Clearly, in contrast to the book, which would have been much more expensive and was chiefly intended for the regular zoo visitor (Ibid., VI), the other three publications were more broadly accessible and linked to visitors' more immediate and perhaps, only, experience of the zoo.

${ }^{4}$ Hagenbeck Archive: newspaper clippings: W. Henz, "Der Neue Hagenbecksche Tierpark in Stellingen bei Hamburg" (1907).

5 Still, one of my anonymous reviewers has pointed out that recent analyses of the Comte de Buffon's Histoire Naturelle and of Alfred Brehm's Thierleben also reveal a predominance of anthropomorphisms and subjective descriptions similar to those discussed in this paper. This would suggest the widespread use of these discursive strategies.

${ }^{6}$ Herman Reichenbach, “A Tale of Two Zoos: The Hamburg Zoological Garden and Carl Hagenbeck's Tierpark,” in New Worlds, New Animals: From Menagerie to Zoological Park in the Nineteenth Century eds. R. J. Hoage and William A. Deiss (Baltimore: Johns Hopkins University Press, 1996), 52-53. A comprehensive history of the Hamburg Zoological Garden as well as its later rival, the Hagenbeck Tierpark, may be found in this article as well.

7 This assertion and the ideas discussed in this article are based on arguments developed further in the author's dissertation, "Of Beasts and Men: Identities, Zoos and the Idea of Civilization in Germany, 1858 to 1914," which is currently being completed at the University of Alberta.

${ }^{8}$ Reichenbach, 53.

${ }^{9}$ Staatsarchiv Hamburg Hansestadt [hereafter StaHH] A585/157 Kapsel 1, Zoologische Gesellschaft u. Zoologischer Garten, J. Vosseler, "Die wissenschaftliche und volksbildende Bedeutung eines zoologischen Gartens im Herzen der Großstadt. Nach einem Vortrag gehalten am 1. Mai 1911 im St. Georger Verein von 1874 von Prof. Dr. Vosseler" (Hamburg: Schröder \& Jeve, 1911), n.p.

10 To be sure, the importance of collection to the Hamburg Zoo (as well as the plenteousness of documents) makes it particularly useful for considering some of these related discourses.

${ }^{11}$ For more nuanced discussions of ethnological and anthropological collection see H. Glenn Penny, "Bastian's Museum: On the Limits of Empiricism and the Transformation of German Ethnology" and Andrew Zimmerman, "Adventures in 
the Skin Trade: German Anthropology and Colonial Corporeality," especially pages 158-161. Both articles are published in Worldly Provincialism, German Anthropology in the Age of Empire, eds. H. Glenn Penny and Matti Bunzl (Ann Arbor: The University of Michigan Press, 2003), 86-126 and 156-178 respectively.

${ }^{12}$ StaHH A585/159 Kapsel 1, Zoologischer Garten, A. E. Brehm, Verzeichniß der lebenden Thiere des Garten zu Hamburg (Hamburg: Verlag der Zoologischen Gesellschaft, 1863), 68.

${ }^{13}$ StaHH A585/159 Kapsel 1, Zoologischer Garten, Heinr. Bolau, Fübrer durch den Zoologischen Garten (Hamburg: Verlag der Zoologischen Gesellschaft, 1891), 17.

${ }^{14}$ StaHH A585/159 Kapsel 2, Zoologischer Garten, Julius Vosseler, Fübrer durch den Zoologischen Garten in Hamburg (Hamburg: Verlag der Zoologischen Gesellschaft, 1911), 5.

${ }^{15}$ At their most minimal, these descriptions focused purely on a single aspect of an animal. In a pamphlet that described the important role of the Hamburg Zoo, Dr. Vosseler commented that "One laughs about the unexpected dexterity of the bears, is amazed by the majesty of the lions, the height of the giraffes or the massiveness of the pachyderms ... (StaHH A585/157 Kapsel 1, Zoologischer Garten, Vosseler, n.p.)." These portrayals obviously characterized animals as the simplest of entities.

16 StaHH A585/159 Kapsel 1, Zoologischer Garten, Brehm (1863), 47.

${ }^{17}$ StaHH A585/159 Kapsel 1, Zoologischer Garten, Bolau (1891), 25.

${ }^{18}$ StaHH A585/159 Kapsel 2, Zoologischer Garten, Vosseler (1911), 21, 53.

${ }^{19}$ Thomas Laqueur, Making Sex: Body and Gender from the Greeks to Freud (Cambridge, Mass.: Harvard University Press, 1990), 166.

${ }^{20}$ StaHH A585/159 Kapsel 1, Zoologischer Garten, Brehm (1863), 21-22.

${ }^{21}$ StaHH A585/157 Kapsel 3, Zoologische Gesellschaft u. Zoologischer Garten (1906-1907), Heinrich Bolau, "Unsere Biber. I. Biber mit Jungen," Zoologischer Garten in Hamburg 5 (1906): 1. Note that Max and Moritz are the names of two notoriously incorrigible boys in the classic German stories of the same name by Wilhelm Busch (1832-1908).

${ }^{22}$ Ibid. Similarly, in a two-part series of articles in the zoo's concert magazine, the zoo's Indian elephant, Anton, was described in the first article in a similarly representative way. He is mentioned at the beginning of the article as a lead-in to describing Indian elephants in general. It should be added, however, that exceptionally, the second article in the series focused on Anton as an individual, describing his arrival in Hamburg and at the zoo and then anthropomorphically used the "voice" of Anton to describe his experience of the move to his new building enclosure (StaHH A585/157 Kapsel 3, Zoologische Gesellschaft u. Zoologischer Garten, Heinrich Bolau, "Erste 'Anton' - Nummer," Zoologischer Garten in Hamburg 5 [1904]: 1-3; StaHH A585/157 Kapsel 3, Zoologische Gesellschaft u. Zoologischer Garten, Heinrich Bolau, “Zweite 'Anton' - Nummer," Zoologischer Garten in Hamburg 6 [1904]: 1-4). Even so, after his death, Anton was replaced with another elephant, generically named “Anton II” (StaHH A585/159 Kapsel 2, Zoologischer Garten, Vosseler [1911], 67-68).

${ }^{23}$ StaHH A585/159 Kapsel 2, Zoologischer Garten, Vosseler (1911), 28.

${ }^{24}$ StaHH A585/159 Kapsel 1, Zoologischer Garten, Brehm (1863), 57.

${ }^{25}$ StaHH A585/157 Kapsel 1, Zoologische Gesellschaft u. Zoologischer Garten, Vosseler, n.p.; Herbert Weidner, Bilder asu der Geschicbte des Zoologischen Museums der Universität Hamburg. Die Zoologischen Sammlungen im Naturbistorischen Museum ₹u Hamburg wäbrend seiner Kollegialverfassung 1843 bis 1882, Mitteilungen aus dem Hamburgischen Zoologischen Museum und Institut, Ergänzungsband zu Band 90 (Hamburg: Selbstverlag des Zoologischen Instituts und Zoologischen Museums der Universität Hamburg, 1993), 161.

${ }^{26}$ StaHH A585/157 Kapsel 2 Zoologische Gesellschaft u. Zoologischer Garten, Zoologischer Garten Anzeiger 1 (April 1880), n.p..

${ }^{27}$ For examples from Dr. Vosseler's guidebook see StaHH A585/159 Kapsel 2, Zoologischer Garten, Vosseler (1911), 6, 37, 45, 64 .

${ }^{28}$ StaHH A585/159 Kapsel 1, Zoologischer Garten, Brehm (1863), 79.

${ }^{29}$ StaHH A585/159 Kapsel 1, Zoologischer Garten, Bolau (1891), 69. In this instance, Bolau does not even describe the appearance, physiology or diet of the animal. Instead, his only other comments relate to its temperament: "The wild yaks are diligently pursued; the tame [yak] shows a good-natured disposition; only during rutting season is the bull very malicious, wild and excited (Ibid.)." In addition, one of my anonymous reviewers interestingly notes that a similar statements about the yak may be found in the Official Guidebook of the San Diego Zoo, $1^{\text {st }}$ edition (1944). This suggests the pervasiveness and persistence of the discourse discussed in this paper.

${ }^{30}$ Carol J. Adams, The Sexual Politics of Meat: A Feminist-Vegetarian Critical Theory (New York: The Continuum Publishing Company, 1994), 47. 
31 The descriptive content of the older (1863) guidebook was largely retained in the 1865 version, although not always in the same order or groupings. It was also expanded with new descriptions and images of animals (the 1863 edition had no illustrations of animals).

${ }^{32}$ For the grotto image see StaHH A585/159 Kapsel 1, Zoologischer Garten, A. Brehm, Führer durch den Zoologischer Garten zu Hamburg (Hamburg: Verlag der Zoologischer Gesellschaft, 1865), 65.

33 Unfortunately not all of the copyright holders for the images reproduced in Figures 1-11 could be traced. The author would gladly receive any further information pertaining to these images.

34 The exception is the illustration of the Wombat House. Yet even in the wombat illustration, where the enclosure appears to be circular and therefore permits a frontal view of two visitors, a man and a boy, looking in from the other side, it is clear that it is the animal that is the object of attention. Rather than adopt the animal's perspective by showing its back as it looks upon its observers, the animal is shown facing the direction of the reader, not returning the gaze. Instead, the wombat is shown scratching itself and appears oblivious to being observed (Ibid., 18). The choice of this illustration is curious since the book Bilder und Skizzen aus dem Zoologischen Garten zu Hamburg contains a very similar image of the wombat in its enclosure by the same artist, Th. F. Zimmerman. In this case, there are no visitors shown looking at the animal, which instead looks towards the reader (Ibid., 81). However, the second image is consistent with others in the book that direct the viewer's gaze to the bodies of the animals, in isolated enclosures or in a natural setting, rather than trying to replicate the zoo visitor's experience as occurs in the guidebooks. See below.

35 StaHH A585/159 Kapsel 1, Zoologischer Garten, Brehm (1865), 19, 33, 50, 56.

${ }^{36}$ Brehm's departure from the zoo was controversial, although the actual reasons for the parting of ways were never made fully public. Brehm had already tendered his resignation on February 26, 1866 effective May 1, 1867. However, things came to a head in discussions about the planned building of the zoo's restaurant, bird and reptile houses, whereupon he was immediately fired on November 28, 1866 (Weidner, 168).

37 StaHH A585/157 Kapsel 2, Zoologische Gesellschaft u. Zoologischer Garten, Eugen Richter, "Geschichte des Zoologischen Gartens in Hamburg (Fortsetzung)," Zoologischer Garten-Anzeiger 21 (September 1880), n.p.

${ }^{38}$ It should be noted that although for the sake of presentation I have selected the 1901 handbook image shown in Figure 5, it is in fact identical to that of the 1891 guidebook. The only difference between them is some additional text pertaining to the donor of the African elephant teeth. The older image may be found in StaHH A585/159 Kapsel 1, Zoologischer Garten, Bolau, 95. In addition the fourth image I am referring to in the 1891 handbook was the head of the wart hog shown in Figure 8 below. Interestingly the later 1901 edition, which no longer contained any of the images from Brehm's guide, also included the figure of a hippopotamus head in profile. For that image see StaHH A585/159 Kapsel 1, Zoologischer Garten, Heinr. Bolau, Führer durch den Zoologischen Garten zu Hamburg (Hamburg: Verlag der Zoologischen Gesellschaft, 1901), 118. This later edition also included an image of a chimpanzee seated on a platform eating fruit and holding a rope. See Ibid., 33.

39 Weidner, 193.

40 StaHH A585/157, Kapsel 2, Zoologische Gesellschaft u. Zoologischer Garten, "Unsere Raubthiere im Zoologischen Garten," Zoologischer Garten-Anzeiger 1 (April 1880)." In German, "Zergliedern", which is the word used in the original text, has three possible meanings: to analyse, dissect or dismember. All of these are consistent with my argument, although the term "dissect" is generally the translation applied to plants and animals.

${ }^{41}$ Bruno Oetteking, Ein Beitrag zur Kraniologie der Eskimo mit einem Anhange über Eskimo-Steingräber im nordöstlichen Labrador und das Sammeln anthropolgischen Materials aus solchen von Bernhard Hantzsch, (Berlin: Teubner, 1908).

${ }^{42}$ In her study of German anthropologists' use of cinema Assenka Oksiloff asserts that in many respects the Kinematograph was intended to replace the camera as a means of dispassionately recording data (Picturing the Primitive. Visual Culture, Ethnography, and Early German Cinema [New York: Palgrave, 2001], especially Chapter 1, but also 51-3). Oksiloff suggests that the isolated human specimen emphasizes the physical characteristics of the body, while at the same time images of people in their 'natural settings,' sometimes performing ordinary activities, imparted an aspect of narrative fantasy to the ethnographic film, giving it a documentary effect that was equally objectifying (Ibid., 18-19).

43 StaHH A585/159 Kapsel 1, Zoologischer Garten, Bolau (1891), 25.

44 Ibid., 72.

45 Ibid., 68.

46 Ibid.

${ }^{47}$ Ibid.

48 G. Grimpe, “Julius Vosseler zum 70. Geburtstage,” Der Zoologische Garten 4, no. 10/12 (1931): 314-315.

49 Vosseler's spare, scientific approach was undercut by the apparent confusion of images found in his guidebook, which now contained mostly, but not exclusively, photographs. Despite the sleek and modern-looking appearance of his handbook it nevertheless contained a pastiche of perspectives including some from previous guidebooks. For example, 
the stag pictured in Figure 11 above (from the 1901 handbook) is reproduced on page 5 of Vosseler's handbook. For examples of isolated animals in Vosseler's guide see StaHH A585/159 Kapsel 2, Zoologischer Garten, Vosseler (1911), 24, 67. Among the stark images was also a photograph showing the full body profiles of a long and a short-snouted crocodile, thereby making a subtle comparison between the two animals (27). The beaver is seen on p.18. For other examples of natural settings see p.p. 31,35. The majority of the images tended to resemble the anthropological representations described by Oksiloff featuring the subjects either in relative isolation, tightly framed against a stark backdrop or conversely set in context against a naturalistic setting, such as a photo of a beaver shown gnawing a tree beside another chewed-off tree stump and another image of water birds shown at one of the zoo's ponds. Such images, whether isolated or "natural," objectified their subjects by either focusing attention on their bodies or by placing them within a narrative context. See above.

${ }^{50}$ StaHH A585/159 Kapsel 2, Zoologischer Garten, Vosseler (1911), 10-11, 18.

51 Ibid., 43.

52 Ibid., 65.

${ }^{53}$ For examples from all of the Hamburg Zoo directors see StaHH A585/159 Kapsel 1, Zoologischer Garten, Brehm (1863), 77 and (1865), 24, 56; StaHH A585/159 Kapsel 1, Zoologischer Garten, Bolau (1891), 34-35, 37, 39 and (1901), 9, 14, 30, 48; and StaHH A585/159 Kapsel 2, Zoologischer Garten, Vosseler (1911), 7, 9-10, 37, 42. Many examples also included the name and location of the person making the donation.

${ }^{54}$ StaHH A585/157 Kapsel 2, Zoologische Gesellschaft u. Zoologischer Garten: "Unsere Raubthiere im Zoologischen Garten. (Fortsetzung.) B. Die Hunde.” Zoologischer Garten-Anzeiger 6 (May 1880).

${ }^{55}$ For examples from the handbooks see StaHH A585/159 Kapsel 1, Zoologischer Garten, Brehm (1863), 9, 36, 64; StaHH A585/159 Kapsel 1, Zoologischer Garten, Bolau (1891), 3, 21-22, 29; and StaHH A585/159 Kapsel 2,

Zoologischer Garten, Vosseler (1911), 47, 56, 69.

${ }^{56}$ In the United States, the future co-founder and director of the Bronx Zoo in New York, William T. Hornaday, envisioned the creation of a zoological park in which it would be possible to breed endangered animals such as the bison. This led to the foundation of such a zoo at the Smithsonian Institution in Washington, D.C. (Elizabeth Hanson, Animal Attractions: Nature on Display in American Zoos [Princeton \& Oxford: Princeton University Press, 2002], 26). The reservation system created for North American aboriginal peoples might be seen as the human equivalent of the conservation park. In the words of Karl May, "So that the bison does not die out, one provides it with a place of refuge up in the national park in Wyoming. Why does one not also offer the former, rightful master of the land a place where he can live securely and grow mentally (Karl May, Winnetou I, Ungekürzte Volksausgabe [Vienna and Heidelberg: Karl May Taschenbücher im Verlag Carl Ueberreuter, 1953], 7)?”

${ }^{57}$ Jane Goodall's studies of chimpanzees in Tanzania are a good example of the complexity of wild animal "societies." ${ }^{58}$ StaHH A585/157 Kapsel 2, Zoologische Gesellschaft u. Zoologischer Garten, Eugen Richter, "Unsere Schwätzer im Zoologischen Garten. Schluß.”, Zoologischer Garten-Anzeiger 25 (September, 1880), n.p..

\section{Bibliography}

\section{Libraries, Archival and other Historical Materials}

Brehm, R.L. Bilder und Skizzen aus dem Zoologischen Garten zu Hamburg. Hamburg: M. H. W. Lührsen, 1865.

Grimpe, G. "Julius Vosseler zum 70. Geburtstage.” Der Zoologische Garten 4, no. 10/12 (1931): 313317.

Hagenbeck Archive, newspaper clippings.

May, Karl. Winnetou I. Ungekürzte Volksausgabe. Vienna and Heidelberg: Karl May Taschenbücher im Verlag Carl Ueberreuter, 1953.

Oetteking, Bruno. Ein Beitrag zur Kraniologie der Eskimo mit einem Anhange über Eskimo-Steingräber im nordöstlichen Labrador und das Sammeln anthropolgischen Materials aus solchen von Bernhard Hantzsch. Berlin: Teubner, 1908. 
Stenz, Hermann. Die Vivisektion in ibrer wabren Gestalt. Unwiderlegliche Tatsachen aus der

Fachliteratur. Berlin: Weltbund zur Bekämpfung der Vivisektion, 1899.

Stiftung Historische Museen Hamburg/Altonaer Museum, Archiv der Graphik und Zeichnungen

"Bilderbogen Schiessscheibe", Verlag Gustav Kühn, Neuruppin.

Staatsarchiv Hamburg (StaHH) A585/159 Kapsel 1 \& 2, Zoologischer Garten; A585/157 Kapsel 1, $2 \& 3$, Zoologische Gesellschaft u. Zoologischer Garten.

Treuberg, Ernst. Gang durch den Zoologischen Garten. No publishing information, c. 1900.

\section{Secondary Sources}

Adams, Carol J. The Sexual Politics of Meat: A Feminist-Vegetarian Critical Theory. New York: The Continuum Publishing Company, 1994.

Hanson, Elizabeth. Animal Attractions: Nature on Display in American Zoos. Princeton \& Oxford: Princeton University Press, 2002.

Laqueur, Thomas. Making Sex: Body and Gender from the Greeks to Freud. Cambridge, Mass.: Harvard University Press, 1990.

Oksiloff, Assenka. Picturing the Primitive. Visual Culture, Ethnography, and Early German Cinema. New York: Palgrave, 2001.

Penny, H. Glenn. "Bastian's Museum: On the Limits of Empiricism and the Transformation of German Ethnology." In Worldly Provincialism, German Anthropology in the Age of Empire, eds. H. Glenn Penny and Matti Bunzl, 86-126. Ann Arbor: The University of Michigan Press, 2003.

Reichenbach, Herman. "A Tale of Two Zoos. The Hamburg Zoological Garden and Carl Hagenbeck's Tierpark." In New Worlds, New Animals: From Menagerie to Zoological Park in the Nineteenth Century, eds. R. J. Hoage and William A. Deiss, 51-62. Baltimore: Johns Hopkins University Press, 1996.

Weidner, Herbert. Bilder asu der Geschichte des Zoologischen Museums der Universität Hamburg. Die Zoologischen Sammlungen im Naturbistorischen Museum zu Hamburg während seiner Kollegialverfassung 1843 bis 1882. Mitteilungen aus dem Hamburgischen Zoologischen Museum und Institut, Ergänzungsband zu Band 90. Hamburg: Selbstverlag des Zoologischen Instituts und Zoologischen Museums der Universität Hamburg, 1993.

Zimmerman, Andrew. "Adventures in the Skin Trade: German Anthropology and Colonial Corporeality." In Worldly Provincialism, German Anthropology in the Age of Empire, eds. H. Glenn Penny and Matti Bunzl, 156-178. Ann Arbor: The University of Michigan Press, 2003. 